〈症例〉

\section{EUS-FNAによって扁平上皮癌と 診断し得た原発不明後腹膜腫瘍の} 1 例

\author{
大村卓也 ${ }^{1 \text { * }}$ 西村 誠 ${ }^{2)}$ 新井冨生 ${ }^{3)}$ 金澤伸郎 ${ }^{4)}$ \\ 三井秀雄 ${ }^{4)}$ 弥勒寺紀栄 ${ }^{11}$ 田村優子' ${ }^{1)}$ 中嶋研一朗 ${ }^{1}$ \\ 佐々木美奈 ${ }^{11}$ 上坦佐登子 ${ }^{11}$
}

\footnotetext{
1) 東京都健康長寿医療センター / 消化器内科, ${ }^{2}$ 同 $/$ 内視鏡科, 3) 同 / 病理診断科, ${ }^{4)}$ 同 /外科

*Corresponding author : takuya_oomura@tmghig.jp

〔Key Words〕 原発不明癌, EUS-FNA
}

\section{症 例}

患者：80歳, 男性。

主訴：腹部圧迫感。

既往歴：虫垂炎, 高血圧症, 脂質異常症, 前立腺癌。 現病歴：2013年 2 月頃から食後に腹部の重苦しさを 自覚し, 5 月中旬当院紹介受診した。腹部造影 $\mathrm{CT}$ (Fig. 1) と造影 MRI (Fig. 2) から, 十二指腸GIST と転移性 肝腫瘍が疑われた。治療にあたり後腹膜腫瘍から病理 組織検査が必要と考えられ，6月中旬EUS-FNA目的 に入院となった。

EUS-FNA：十二指腸内腔は保たれていた。下十二 指腸角内側に $76 \times 40 \mathrm{~mm}$ の表面不整な充実性腫瘍を認 め, 内部は不均一で中心部は壊死様であった。

病理組織学的所見 $($ Color 1, 2)：細胞診では壊死 組織に混在して角化様のオレンジG好性胞体を持つ 細胞を認めた。免疫染色はp $63+, \mathrm{CEA}-$, PSA - , Calretinin -, KIT-, DOG1-であり, 癌腫の転移, 扁平上皮癌が第一に考えられた。

臨床経過：後腹膜腫瘍が扁平上皮癌であったため原 発巣検索を行ったところ, 上行結腸にtype 2の進行大 腸癌を認め, 生検結果は腺癌であった。入院から約 1 力月後の 7 月に右半結腸切除術, 肝部分切除術, 後腹 膜腫瘍摘出術を施行した。上行結腸癌は中分化から高 分化腺癌でリンパ節転移を認めず，後腹膜腫痬と肝転 移巣は分化傾向の乏しい扁平上皮癌であった。以上の 結果から肝転移を伴う後腹膜腫瘍 (SCC) および上行結 腸癌の重複癌と考えられた。術後にFDG-PETを追加 したところ肝内に再発病変を認め, 原発不明癌診療ガ イドラインに照らし，予後不良群 1 次治療に準じた形 で加療中である。

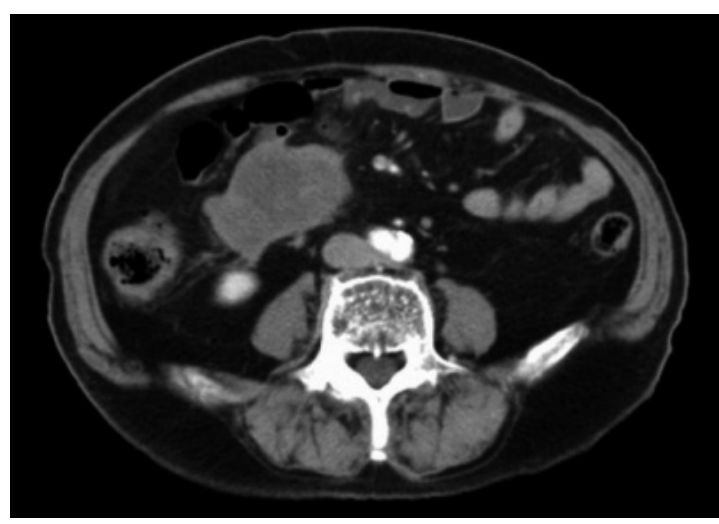

Fig. 1 Retroperitoneal tumor. Axial contrast-enhanced computed tomographic image showing a retroperitoneal tumor measuring $6.4 \mathrm{~cm}$ in diameter adjacent to the inferior angle of the duodenum. The luminal surface of the duodenum is intact. The mass could be suspected as a gastrointestinal stromal tumor, other gastrointestinal mesenchymal tumors, or lymphoma.

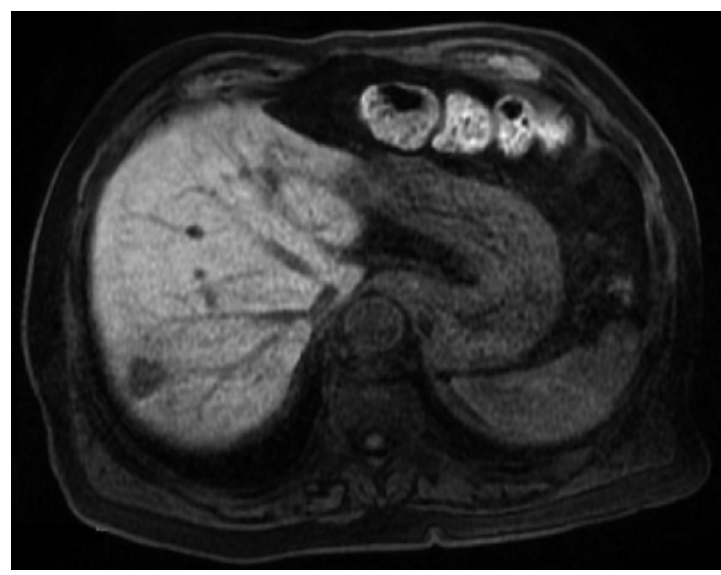

Fig. 2 Metastatic liver tumor. Magnetic resonance imaging showing a space-occupying lesion measuring $2 \mathrm{~cm}$ in diameter in the posterior segment of the right hepatic lobe. This lesion showed an enhancement pattern similar to that of the retroperitoneal tumor; therefore, it was believed to be a metastatic tumor.

\section{考 察}

腸間膜腫瘍および後腹膜腫瘍はその多くが転移性で あり，原発性腸間膜腫瘍は全入院患者中で $1 / 8$ 千人 $1 / 5$ 万人に認められる ${ }^{1)}$ 。その中でも癌腫はわずかに 1.8 〜 $8 \%$ を占める程度とされる

後腹膜に癌腫が発生する理由として, 先在する後腹 膜体膑上皮が，粘液性あるいは槳液性化生を経て癌化 するという仮説が支持されている ${ }^{4)}$ 。後腹膜に癌腫を 認めた時に, 原発巣と考えられる病変を認めず, さら に検体から粘液性や漿液性化生の証拠を認めた場合に, 原発性後腹膜癌と診断することが合理的と考えられる。 
今回我々が経験した症例では病理組織学的に化生の痕 跡を認めず，原発不明扁平上皮癌として治療方針を決 定した。

原発不明癌は文字通り原発巣を指摘できない癌腫 を指すが，その機序として原発巣の自然退縮 (spontaneous regression) を示唆する報告が複数あり, 数字 の正確さに関して議論があるものの約 $1 / 8 \sim 10$ 万症例 に認められる ${ }^{5,6)}$ 。それゆえ，精查で原発巣を指摘でき なかったとしても，その事実のみをもって「原発癌」 と診断することは慎重を期すべきと考えられる。

新しい穿刺針などの登場により診断成績が向上し, EUS-FNAの果たす役割は拡大している FNAを行うかどうかを決定する最も重要な要素は, 細胞診の結果によって治療方針が変わるかどうかであ るが ${ }^{9}$ ，自験例でもその後の治療方針の選択に有用で あった。穿刺針の太さや形状に関してはさらなる検討 が必要であるが，後腹膜の原発不明癌において非常に 有用な検査であると考えられる。

\section{おわりに}

EUS-FNAは, CTやMRI検査に加え, 病理組織学 的診断も可能であることから，有用な診断ツールと考 えられる。後腹膜や腸間膜に指摘された癌腫において, 原発巣を指摘できなかった場合，慎重な検討が必要に なると考えられる。

\section{文 献}

1 ）沖田理貴, 佐伯修二, 向田秀則, 他：横行結腸間膜原発巨 大脂肪腫の 1 例：日消外会誌，36：1708-1712，2003.

2 ）山本誠己，勝部宥二，奥 勝治，他：原発性腸間膜血管肉 腫の 1 例：臨外, 34：285-290, 1979 ,

3 ) Pinson CW, ReMine SG, Fletcher WS et al : Long-term results with primary retroperitoneal tumors. Arch Surg, $124: 1168-1173,1989$.

4) Chen CH, Yeh SD, Chiou JF et al : Optimum Treatment for Primary Squamous Cell Carcinoma of the Pelvic Retroperitoneum. JECM, 3: 304-306, 2011.

5 ) Jessy $\mathrm{T}$ : Immunity over inability : The spontaneous regression of cancer. J Nat Sci Biol Med, $2: 43-49,2011$.

6 ) O'Regan B, Hirshberg C : Spontaneous Remission : An Annotated Bibliography. p13, Institute of Noetic Sciences, CA, 1993.

7 ) Iglesias-Garcia J, Poley JW, Larghi A et al : Feasibility and yield of a new EUS histology needle: results from a multicenter, pooled, cohort study. Gastrointest Endosc, 73 1189-1196, 2011
8 ) Sofi AA, Thekdi AD, Nawras A : EUS-FNA for the Diagnosis of Retroperitoneal Primitive Neuroectodermal Tumor. Diagn Ther Endosc, doi 10.1155/2011/198029, 2011.

$9)$ Raj M, Chen RY : Interventional applications of endoscopic ultrasound. J Gastroenterol Hepatol, 21 : 348—357, 2006.

〈カラーはp. 11に掲載〉

\section{Retroperitoneal squamous cell carcinoma with unknown primary diagnosed by endoscopic ultrasound-guided fine needle aspiration}

$\begin{array}{ll}\text { Takuya Omura }^{1) *} & \text { Makoto Nishimura } \\ \text { Tomio Arai }{ }^{3)} & \text { Nobuo Kanazawa } \\ \text { Hideo Mitsui }^{4)} & \text { Kie Mirokuji } \\ \text { Yuko Tamura }^{1)} & \text { Kenichiro Nakajima }{ }^{1)} \\ \text { Mina Sasaki }^{1)} & \text { Satoko Uegaki }\end{array}$

An 80-year-old male presenting with abdominal distension was referred to our institution after being detected to have a positive test for fecal occult blood. Computed tomography revealed a retroperitoneal tumor. Endoscopic ultrasound-guided fine needle aspiration (EUS-FNA) showed an invasive mass inside the inferior duodenal angle, and cytological examination confirmed the diagnosis of squamous cell carcinoma (SCC). Despite careful examination, the origin of the tumor remained unclear. Analysis of specimens obtained during right hemicolectomy, partial hepatectomy, and mesenteric tumor resection confirmed the diagnosis of SCC.

Typically, retroperitoneal carcinoma is a metastatic cancer, and primary retroperitoneal carcinoma is extremely rare. This paper describes a case of retroperitoneal SCC diagnosed by EUS-FNA and considered as a case of carcinoma of unknown primary (CUP). According to a widely accepted hypothesis about the onset of primary cancer in the retroperitoneum, these cancers arise from serous or mucinous metaplasia of pre-existing retroperitoneal coelomic mesothelium. In our case, the tumor specimens revealed no serous or mucinous metaplasia; therefore, the diagnosis of retroperitoneal SCC with CUP was considered more reasonable.

If a carcinomatous lesion does not contain an epithelial component, it is unlikely to be a primary tumor. In this case, EUSFNA strongly suggested the diagnosis of SCC before surgery; therefore, the treatment course was changed. Thus, EUS-FNA was useful both for diagnosis and selection of the therapeutic strategy.

1) Department of Gastroenterology, 2) Department of Endoscopy, ${ }^{3)}$ Department of Pathology, ${ }^{4}$ Department of Surgery, Tokyo Metropolitan Geriatric Hospital

*Corresponding author : takuya_oomura@tmghig.jp 